\title{
The Effectiveness of Implementation Family Planning Village Program at Village Beting of Bugis Dalam Subdistrict East Pontianak District in Pontianak City And Village Sepadu Semparuk District Sambas Regency
}

\author{
Rianawati $^{1 \mathrm{a},}$ Aida Mokhtar ${ }^{1}$, M. Lutfi ${ }^{1}$, GMS. Primastuti ${ }^{1}$ \\ ${ }^{1}$ National Family Planning Coordinating Agency of West Kalimantan (BKKBN) \\ irin_ptk@ymail.com \\ Whatsapp Number $\{+6282148263025\}$
}

\section{ARTICLE HISTORY}

Received: 15 January 2019

Revised: 28 February 2019

Accepted: 17 March 2019

Copyright $\odot 2019$ Authors \& Published by IIES Independent. This is an open-access article distributed under the terms of the CC-BY-SA License.

\section{ABSTRACT}

This study is motivated by the high rate of Total Fertility Rate (TFR) in West Kalimantan, which is at 3.1 children per woman. In addition, information was also found that unwanted and unplanning pregnancies were still high at 9.1 percent, unmet need in 2016 was still 15.8 percent, and the development in family planning participation in the recent decade was still very slow. Generally, this study aims to determine the effectiveness of the implementation of the KB Village. The study conducted in this study is an evaluative study with data collection carried out through quantitative and qualitative approaches. The qualitative approach aims to obtain indepth information about input, process, implementation, monitoring, evaluation and reporting as well as achievement indicators of success. Meanwhile, the quantitative approach was carried out using a structured questionnaire to obtain knowledge, attitudes and community participation related to activities contained in the KB Village Program. The results obtained in this study are the number of active MKJP participants increased from 18 people initially to 28 people. In the aspect of unmet need before the declaration, $22.94 \%$ decreased to $19.49 \%$ 8) Community knowledge and participation related to activities and programs in the $\mathrm{KB}$ Village Beting Village all the people received information about the KB Village from the PPKBD / Sub PPKBD cadres, namely as many as 34 people (68\%). Whereas in Sepadu Village, information about the KB Village was obtained from 7 people (14.29\%) from PPKBD / Sub PPKBD cadres, the rest was obtained from community leaders of 14 people $(28.59 \%)$, other sources were 10 people $(20,41 \%)$, from PLKB/PKB as many as 5 people $(10.20 \%)$, PKK as many as 2 people $(4.08 \%)$ and from nurses/midwives as many as 1 person $(2.04 \%)$. There is no public participation outside the management in Beting, while in Sepadu there are 62 people. Keywords: Implementation; Program; Village Family Planning

How to Cite: Rianawati, M., Mokhtar, A., Lutfi, M., Primastuti, G. (2020). The Effectiveness of Implementation Family Planning Village Program at Village Beting of Bugis Dalam Subdistrict East Pontianak District in Pontianak City And Village Sepadu Semparuk District Sambas Regency. International Journal of Advances in Social and Economics, 2 (3), 136-144. DOI : https://doi.org/10.33122/ijase.v2i3.161

\section{Introduction}

The National Population and Family Planning Agency $(\mathrm{BKKBN})$ is one of the Non-Ministry Institutions that has the mandate to realize the Development Priority Agenda (Nawacita) Government of the 2015-2019 period, especially on the 3rd Priority Agenda "Building
Indonesia from the Edge by Strengthening Regions and Villages in the framework of the Unitary State", the 5th Priority Agenda "Improving the Life Quality of Indonesian People" and the 8th Priority Agenda is "Revolution of the Nation's Character through Population and Family Planning Development". An effort to realize the priority agenda, the BKKBN must be able to implement the 2015-2019 National 
Development Strategy (on the National Development Dimension) with a focus on developing the Health and Mental/Character Development (Mental Revolution) Dimensions to be integrated into the Population, Family Planning and Family Development Program (KKBPK).

The development of the strategic environment and the direction of the Government development policies for the 2015-2019 period above are then elaborated in the Provincial Medium-Term Development Plan (RPJMP) and the BKKBN Strategic Plan (Renstra) for 20152019, with 6 (six) Strategic Targets that have been set; (1) reducing the average Provincial Population Growth Rate (LPP) (percent per year) from 1.66 percent/year in 2015 to 1.40 percent in 2019; (2) Reducing the Total Fertility Rate (TFR) per woman of reproductive age from 3.1 in 2012 to 2.6 in 2019; (3) increasing contraceptive prevalence rate (CPR) for all methods from 67 percent to 69 percent; (4) the decline in unmet need family planning needs from the number of fertile age couples (percent) from 9.5 percent in 2015 to 8.3 percent in 2019; (5) the decline in Age Specific Fertility Rate (ASFR) from 90 (in 2015) to 70 per 1,000 women in the 15-19 age group in 2019; (6) the decrease in the percentage of unwanted pregnancies of Fertile Women from 7.1 percent in 2015 to 6.6 percent in 2019.

The goal of reducing the rate of population growth is due to the population growth rate which is directly proportional to the population quantity. The increase in LPP will make it difficult for the government to provide basic needs of the population, such as clothing, food, housing, jobs and income. Based on 2015 Interdental Population Survey (SUPAS) data, the rate of population growth in Indonesia in 2016 was 1.43 percent. When compared with the results of the Population Census (SP) in 2010, LPP decreased by 0.06 percent, where in 2010 LPP was 1.66 percent.

The results of the 2012 Indonesian Demographic and Health Survey (SDKI) showed that the total fertility rate of West Kalimantan (TFR) was quite high at 3.1 children per woman. In addition to the IDHS, another survey that annually measures the TFR is a survey of the RPJMN KKBPK program performance indicators. Based on the 2016 RPJMN KKBPK program performance survey, TFR West Kalimantan 2.30 children per woman. Likewise with the participation in KB (Contraceptive Prevalence Rate) there has been an increase in the use of modern contraception, but the increase in the past decade has been quite slow. The increase in use of modern contraception increased from 41.4 percent (1991 IDHS) to 50.6 percent (1994
IDHS), then to 58.1 percent (1997 IDHS), 57.8 percent (2002 IDHS) and increased to 62.7 percent (2007 IDHS), and increased again to 65.1 percent (2012 IDHS). The CPR calculation for all methods in 2017 based on a survey of the RPJMN KKBPK program performance indicators is 60.8 percent.

Unmet need for family planning services (unmet need) is a measure of the extent to which the KKBPK Program has met the needs of the community, especially EFA. Based on the 2016 RPJMN KKBPK Program Performance Indicators Survey, the unmet need for 2016 was 15.8 percent. The strategic target of birth rates for adolescents aged 15-19 years, based on survey data on the performance indicators of the 2016 RPJMN KKBPK program is 35 per 1,000 births. Unwanted pregnancy is an important indicator to determine the risk of maternal and children mortality. Survey data on the performance indicators of the 2016 RPJMN KKBPK program show that pregnancy is unwanted by 9.1 percent.

KB Village is the idea of Indonesian President Joko Widodo, as a national development effort that focuses on development at the lowest level, namely the village. The KB village launched by the President on January 14, 2016 became one of BKKBN's innovation programs in order to improve the implementation of the KKBP Program.

The basic proponents of the KB Village activities come from regional units at the level of citizen association (RW), RW or equivalent which have certain criteria where there is integration of the Population, Family Planning and Family Development program and related sectors which are carried out systemically and systematically (BKKBN, 2017).

In essence of the KB Village was created to improve the quality of life for the people even though they are in the lowest hierarchy of government. For this reason, the implementation is also carried out at the village level or equivalent through population activities; family planning and reproductive health; family resilience and empowerment (family development); and the development of related sectors (tailored to the needs of the region) in order to realize quality small families (BKKBN, 2017).

In addition, the $\mathrm{KB}$ village was formed to increase cross-sector cohesiveness, so that the intervention was more focused on integrating the implementation of programs and activities with partners, so that in the $\mathrm{KB}$ Village Technical Manual, the special purpose of the $\mathrm{KB}$ village was The $\mathrm{KB}$ village becomes a reflection of 
the implementation of KKBPK Program activities in full and integrated with related cross-sector activities (Ministries/Institutions, work partners, stakeholders, agencies) according to the needs and conditions of the region where the benefits are received directly by the community. In practice the implementation of the program and its activities target all segments of society at the lowest level, such as Fertile

Age Couples (PUS), adolescents, the elderly population, families with children under five, families with adolescents, families with the elderly, and related sector targets according to their respective fields of work respectively. The program implementation also involved all village officials such as Village/Heads of neighbor association, Heads of citizen association, PKB/PLKB/TPD, Field Officers, PKK, PPKBD / Sub PPKBD, Community Leaders/Customary Leaders/Religious Leaders and Cadres.

An area that will be used as a location for implementing the $\mathrm{KB}$ village program has mandatory requirements that must be met, including support and commitment from the Regional Government, availability of accurate population data and information and active participation from the community (BKKBN, 2017). The support and commitment of the Regional Government is obtained through the commitment and active role of all agencies/work units, Regency/City, District and Village/Village Governments in providing support for programs and activities that will be carried out in the $\mathrm{KB}$ village and willing to provide services to the community in accordance with their field of work respective agencies to improve the standard of living of the community. In operational research on the development of the $\mathrm{KB}$ village management model carried out by Dawam and Fadila (2016), the commitment of the Provincial Government and Regency/City Government is seen by following up on the Circular of the Minister of Home Affairs number 440/70 / SJ dated January 1, 2016, Regarding Declaration and Formation of KB Village and Letter of the Head of BKKBN number 046/BL/200/B4/2016 dated January 12, 2016 concerning the Direct Broadcasting and Establishment of $\mathrm{KB}$ Village. The follow-up in question is the existence of a Governor Circular with the preparation of the KB Village selection by the Provincial BKKBN Representative. The results of the selection that have received the commitment and support of all parties are followed up with the launching of the KB Village which was established through the Decree of the Regent/ Mayor.
The successful implementation of $\mathrm{KB}$ village activities is determined by the synergy of the KKBPK Program activities with other agencies/sectors with the aim of improving the welfare of the community in the $\mathrm{KB}$ village. Operational research carried out in Gampong Batee Raya, Juli District, Bireun Regency and Sepa Village Amahai District and Central Maluku Regency, intensive commitment and support was provided by the Population and Civil records and Agriculture Services. (Dawam \& Fadila, 2016). Other mandatory prerequisites are the availability of accurate population data and information sourced from the results of Family Data Collection, Village Potential data and Civil Registration data that can be accurately used as a basis for determining priorities, targets and programs that will be carried out in the KB Village continuously.

The next prerequisite is the active participation of the community, community leaders, religious leaders, traditional leaders and the private sector in the management and implementation of all activities that will be carried out in the KB family in a sustainable manner in order to improve the living standards of all the people in their area. This is in line with the results of operational research on the KB Village that has been carried out, that in the formulation of the "Integrated KB Village Program Management" model, the implementation of its activities cannot be separated from community participation, because the management and implementation of this program can be sustainable if there is participation from and by the community independently (Dawam \& Fadila, 2016).

The implementation of $\mathrm{KB}$ village activities is based on the Allocation of Schedule of Activities (AJK) that has been determined in advance through a preparatory meeting by the relevant Regional Apparatus Organization (OPD) at the Regency level. KB village activities are carried out monthly and weekly at various levels, beginning with district/city level workshops organized by representatives of the Provincial BKKBN. At the sub-district level, a mini workshop was held which was participated by stakeholders. Followed by a mini workshop at the village/sub district level and training of village/sub district cadres (according to the Working Group). After training at the village / sub district level, cadres together with Toga / Toma implement IEC to the community and foster family resilience through group activities and integration of allied programs with other sector activities.

The results of operational research (Dawam \& Fadila, 2017) show that if coordination meetings and forums are held routinely, then the continuity and 
development of activities in the $\mathrm{KB}$ village will be maintained aimed at enhancing the role of the Government, Regional Governments, NonInstitutions Government and private sector in facilitating, providing assistance and coaching to the community so that they will actively participate in improving the quality of life of the community.

Deliberation forum as a forum for coordination of all program developments, both the realization of activities and planned development activities. Indicators of Success in the KB Village are based on several indicators as follows:

\section{The number of PLK / PKB is proportional}

2. Availability of operational support (APBN, ABD, PNPM, ADD, PKH, Jamkesda / Jamkesmas)

3. Availability of operational facilities

4. Increasing the frequency and quality of advocacy activities and IEC

5. Improving the quality of family planning and KR services

6. Periodic group meetings of $\mathrm{BKB}, \mathrm{BKR}, \mathrm{BKL}$, UPPKS, IMP meetings, staff meetings and Mini Workshops

7. Taman Integrated health center services (PAUD, health / integrated health center and BKB), marriage certificate, birth certificate and KTP

8. Availability of data and family maps in each RT / RW

9. Increased achievements of active KB participants

10. Increasing MKJP achievements

11. Increase in the achievements of male family planning members out of a total of KB participants

\section{Decreased unmet need}

13. Increased participation of families who have toddlers in BKB

14. Increased participation of families who have teenagers in BKR

15. Increased participation of families who have elderly in BKL

16. Increased participation of the elderly in BKL

17. Increased adolescent participation in PIK

18. The average age of first marriage of women
19. And other indicators determined by the Ministries / Institutions of Provincial Governments, Regency / City Governments.

Some issues that need special attention include the high TFR (3.1) of women of childbearing age and the increasingly weak implementation of the KKBPK program in the field. Based on the results of the evaluation of activities and program achievements, then several strategic innovations were formulated to strengthen the KKBPK Program for the 2015-2019 period, especially in the form of priority activities that have a leverage on efforts to achieve the targets/ targets set and broaden the scope of the KKBPK program at all levels the region.

As a concrete effort to strengthen the 2015-2019 KKBPK Program, the President of the Republic of Indonesia mandated the BKKBN to compile an activity/program that could strengthen the achievement of targets for the Development of Population and Family Planning Control 2015-2019, could become BKKBN icons and could directly touch and provide benefits to the people of Indonesia at all levels of the region. In this case it was agreed that BKKBN could immediately form the Village of Family Planning (KB Village).

KB Village has become one of the strategic innovations to be able to implement the priority activities of the KKBPK Program as a whole at the lowest level. KB Village is a miniature form/model of the total implementation of the KKBPK Program as a whole which involves all Fields in the BKKBN environment and synergizes with Ministries/Institutions, work partners, relevant agency stakeholders according to the needs and conditions of the region, and is carried out at the lowest level of government (according to prerequisites location determination of $\mathrm{KB}$ villages) in all regencies and cities.

\section{Method}

This research is an evaluative study with data collection carried out through quantitative and qualitative approaches (mixed methods). The qualitative approach aims to obtain in-depth information about input, process, implementation, monitoring, evaluation and reporting as well as achievement indicators of the success of the KB Village Program involving various cross-sectors, namely; Local Government (Pemda), TOGA/TOMA, manager of KB Village and community participation. As for the quantitative 
approach, researchers use it in order to collect data and information in the form of numbers related to the effectiveness of the "village of family planning" program.

In addition, data collection instruments with a qualitative approach were carried out by in-depth interviews with various informants. While the quantitative approach was carried out using a structured questionnaire to obtain an overview of knowledge, attitudes and community participation related to activities contained in the $\mathrm{KB}$ Village Program.

\section{Results and Discussion}

\section{Qualitative Result}

There are three main things that can be taken into consideration as the establishment of the KB Village. First, the availability of accurate population data. Second, the support and commitment of the Regional Government (Pemda), and Third, the active participation of the community. What is meant by accurate population data is the results of data acquisition sourced from family, village potential, and civil registration. The data is considered as an accurate standard data so that it can be used as a basis for determining priorities, targets and programs that will be carried out in the $\mathrm{KB}$ village area or area on an ongoing basis.

The following researchers describe three criteria used in selecting or determining the area that will be the location of the KB Village, namely:

a. The main criteria include two things: (1) The number of Pre-Prosperous (poor) and Prosperous Family (KS) 1 is above the average of Pre-Prosperous and Prosperous Family (KS) 1 at the village / sub district level where the KB Village is located, (2) The number of $\mathrm{KB}$ participants is below the average target achievement of $\mathrm{KB}$ participants at the village / sub district level where the KB Camp is located.

b. Regional criteria, including 10 regional categories (one selected): (1) Slum, (2) Coastal, (3) River Basin (DAS), (4) Railways, (5) Poor Areas (including Urban Poor), (6) Remote, (7) Borders, (8) Industrial Estates, (9) Tourist Areas, (10) Populous Density. Furthermore, in determining the regional criteria that will be used as the location for the formation of the KB Village, one or more of the ten criteria can be selected.

c. Specific Criteria, including 5 things, namely: (1) Data criteria where each RT/RW has Data and Family
Maps, (2) Population criteria where the participation rate of school-age population is low, (3) Criteria of family planning programs where $\mathrm{KB}$ participants Active and Long-Term Contraception Method (MKJP) is lower than the average achievement of the village / sub district level and the level of unmet need is higher than the average level of the village / sub district, (4) Criteria for family development programs where family participation in fostering family security, economic empowerment and youth participation in the activities of Generation Planning (GenRe) through the Center for Youth Information and Counseling (PIK-R) are still low, (5) Criteria for related sector development programs covering at least four areas, namely: health, economy, education, settlement and the environment, and can still be added to other programs in accordance with developments.

Furthermore, from the research data, it was found that information on the formation of KB Village in the Village Beting and Sepadu Villages was based on reason, the main criteria for the formation of $\mathrm{KB}$ Village were the number of Social Protection Card (KPS) and Prosperous Family (KS) 1 holders above the average. Average KPS and KS1 at the village level. Besides that, Village Beting and Desa Sepadu are also areas that are considered to be still slums and remote so that they need more attention. Other criteria which were also fulfilled were specific criteria, which in the aspect of data collection in each RT/RW had accurate population and civil registration data and visible active community participation, from preparation to declaration.

The 2015 Family Data Collection (PK-2015) was carried out in accordance with the mandate of the Law and Government Regulations (Perda) relating to providing family information and data to support the operational and management of the Family Planning and Family Development Population Program (KKBPK). To that end, the central government through the Central BKKBN has established an application system that aims to collect all collected PK2015 data (BKKPPKB DIY, 2015).

Related to the use of 2015 PK data, the data is not the only data used in determining the area or location of the KB Village in this study, because in addition to the data the researcher as explained above also considers other aspects such as regional criteria or maps, data or Routine statistical information and data from across sectors. Utilization of data sourced from Family Data Collection (PK) in the KB Village area in the Beting Village and Sepadu Village areas is not optimal due to incomplete PK data, especially PK 2015, which has not 
yet been returned by the provincial party. Therefore, in order to complete the PK data is incomplete, each Regional Apparatus Organization (OPD) uses supporting data in the form of routine statistical data or data contained in cross-sectors.

From the results of the research interview it can also be seen that the participation and commitment of the Regional Government and cross-sectoral in the implementation of the KB Village program is still very minimal both in the Beting Village and in Sepadu Village. In the Beting Village area, there were only 4 agencies that showed their commitment in relation to $\mathrm{KB}$ villages in 2016, namely the Health Office, the Settlement Office, the Education and Culture Office and the Agriculture Office. In 2017 only 2 agencies carried out special activities in the KB Village, namely the Health Office and the Public Works Office (PU).

For the Sepadu Village area, the commitment of the local government and cross-sector can be said to be better compared to Village Beting, because in 2016 there were 5 agencies that showed their commitment in the KB Village, namely the Health Service, Social Service, Agriculture Service, Fisheries Service and Public Works Service . In 2016, cross-cutting sectors that showed their commitment in the $\mathrm{KB}$ village of Sepadu, such as the Health Office, provided counseling material on Child Trafficking; Children's Day commemoration; outreach and training for the workforce.

Other offices that showed their commitment in the KB Village were the Agriculture Service in the form of Hospitality/ Coordination Entering the 2016 Harvest Period; Development and Formation of Women Farmers Group; Increased Food to Farmers Groups in; Promotion of Agriculture and Plantation Improvement; The Construction of the Farmers Business Road, the Fisheries Office promotes fish culture, the Public Workers Office monitors the irrigation and the socialization of the CommunityBased Drinking Water and Sanitation Program (Pamsimas).

In 2016, the Health Office provided routine Integrated Service Posts (Integrated health center); the Settlement Office undertook infrastructure improvements such as environmental road repairs; improvement of environmental drainage; and revitalizing slums. The Office of Education and Culture provides School Supplies assistance. The Department of Agriculture provides assistance with hydroponic seedlings and fertilizer assistance.
In 2017, there were only two cross-cutting interventions in the Village Beting KB Village, namely the health department with routine integrated health center services and the Public Work Department with natural resources such as trench clearing, Bina marga in road construction, landscaping, Ciptakarya in building facilities. Community service on Saturdays and Sundays. In the same year, 2017, the Health Office conducted mass circumcision activities, free medical treatment, and routine integrated health center services. The Department of Agriculture builds the Irrigation Gate and provides fertilizer and seed assistance. The Public Work Department, through its surname service, is constructing roads and bridges in the KB Sepadu Village, Sambas Regency.

From the explanation of the data above, it is also necessary to convey that the form of activities in the KB Village of Sepadu Village, Sambas Regency since December 2016 to November 2017 has already reached 87 activities. While in Pontianak City Beting Village in the same year, from 2016 to 2017 there were 37 activities.

Furthermore, from the data processing of the research results it was found that the training obtained by the KB Management Team in Village Betimg village consisted of 4 types of training, namely the Technical Training Program of the KKBPK Program for the KB Village Team, Capacity Building for Penglola, KB Cadres and PLKB KB Village, Las Skill Training and Manpower Training KB Village. Implementing Training 3 from BKKN and the rest by BNN.

From the research results also obtained information that the material and frequency of training received by the KB Management Team was felt to be very lacking. The contribution of the Regional Work Unit (SKPD) related to increasing the ability and skills of the KB Management Team in the framework of strengthening and encouraging the success of the KB Village was not yet seen.

Implementers/organizers of training are mostly carried out by BKKBN, cross-sector/partner involvement namely Sambas PKK, Disperindakop and Sambas State Polytechnic. Other technical SKPD involvement in the empowerment/ enhancement of HR has not yet been seen. The training material is more directed at empowering women, such as making dishes from coconut sticks, Training to Improve Children's Creativity (making key chains), training on coconut stick weaving skills in tough women's groups and Training on Making Amplang Crackers. Activities / 
socialization for 2017 in the KB village Sepadu Village until the writing of this report has not been informed.

Regarding the infrastructure available at the KB Beting Village, Communication, Information and Education Media (IEC) Media in the form of KB program banners in front of the $\mathrm{KB}$ village door, Nameplate in front of the KB Service Post and in front of the PIK-R room and in front of the location BKR El-Betinq, there is also a media in the form of a gate that reads various BKKBN slogans, photos of activities are also neatly arranged in the KB Post. Related to the building / room, which is used as a $\mathrm{KB}$ post in Village Beting belongs to the home of one of the original inhabitants of Village Beting

In relation to the building / room, which is used as a $\mathrm{KB}$ post in Village Beting belongs to the home of one of the original inhabitants of Village Beting that has been lent for KB program operations, which until now has also been paid by the owner of the house. In addition there is also the hall of Mr. Ceng which is a multipurpose room that can be used by the $\mathrm{KB}$ village team if needed, the building / hall of the village is also sometimes used to hold an activity carried out for the $\mathrm{KB}$ village.

In contrast to Beting village, in Sepadu village, IEC media are often seen in front of the village hall and at the edges of the Sepadu area, there is also the gate of the Sepadu KB Village, the signposts related to tribina (BKB, BKR, BKL) and UPPKS are also neatly arranged next to the village hall, a bulletin board can also be seen on the porch of the village hall, photographs related to family planning activities are neatly arranged on the information board and there is also a residence corner inside the village hall. For space and all its contents are also available in the village hall as the center of village-level $\mathrm{KB}$ family team association in Sepadu. As for the facilities in the form of MUpen and MUyan, it is the same as in Beting. Namely the village level KB team village does not have it, the existence of these facilities in the Sambas Regency. Thus, the infrastructure needed to carry out the $\mathrm{KB}$ village program has been fully met.

From the information from the Head of the KB Village obtained by researchers in Sepadu Village, it was explained that facilities and infrastructure to support KB Village activities, for example the KIE KKBPK Media, the Information Unit Car, the Service Unit Car, the supporting facilities / buildings, the available space. The same thing was also conveyed by the Semparuk Subdistrict that in order to support the KB Village, IEC was available, house renovations, Mupen
$\mathrm{KB}, \mathrm{KB}$ service car. Facilities and infrastructure (rooms, halls and sound systems), IEC media from related sectors are available.

Support for facilities and infrastructure in the KB Village in both the Pontianak City Kampong Beting Village and in the Sepadu Village Sambas Regency are all available in full, but the problem is the ownership status of the facilities and infrastructure. In Village Beting, for example, buildings such as halls and command posts still have loans because they do not have their own posts. In addition, MUpen and Muyan are only found at the district/city level not at the village /sub district level.

\section{Quantitative Result}

Indicators of program achievement in the KB Village area in Beting Village on the aspect of reducing the number of KPS and KS1 cannot be identified because there is no accurate data collection yet. However, if seen from the number of family planning participants there was a significant increase in the number of preannouncements, namely 411 people and after the announcement, which increased to 471 .

Active participants in the Long-Term Contraception Method (MKJP) also experienced an increase from initially 31 people to 42 people. Unmetneed at the time before the launch amounted to $13.64 \%$ decreased to $11.45 \%$. For the Sepadu Village area, the number of KPS before 263 was announced and there was a decrease after the declaration to 255 . For KS1, at the beginning before the announcement, there were 730 also increased to 767 . While for the number of $\mathrm{KB}$ participants, which initially had 436 people, increased to 517 people. The number of active MKJP participants increased from 18 people initially to 28 people. In the aspect of unmetneed before the announcement, $22.94 \%$ decreased to $19.49 \%$

Knowledge and community participation related to activities and programs in the $\mathrm{KB}$ Village area in Beting Village have been obtained from the PPKBD/Sub PPKBD cadres, as many as 34 people (68\%). Whereas in Sepadu Village, information about the KB Village was obtained from PPKBD / Sub PPKBD cadres, which only amounted to 7 people (14.29\%), the rest information related to the KB village was obtained from community leaders as many as 14 people $(28.59 \%)$, other sources as much 10 people (20.41\%), from PLKB / PKB were 5 people $(10.20 \%)$, PKK were 2 people (4.08\%) and from nurses/midwives were 1 person $(2.04 \%)$. There is no public participation 
outside the management in Beting, while in Sepadu there are 62 people.

\section{Conclusion}

Based on the results of the research discussion, it can be concluded several things as follows:

1. The establishment of KB Village in Beting Village and Sepadu Village has fulfilled three criteria, namely the main criteria, regional criteria and special criteria

2. Utilization of data sourced from Family Data Collection (PK) in the area of Village Beting and Desa Sepadu has not been carried out optimally.

3. Participation and commitment of the Regional Government (Pemda) and cross-sectoral in the implementation of the KB Village program is still very minimal both in Village Beting and in Sepadu Village.

4. The form of KB Village activities that have been realized in Sepadu Village since December 2016 to November 2017 is 87 activities. While in Beting Village, from the same year, from 2016 to 2017, 37 activities have been recorded.

5. The training and mobilization activities by program managers in the $\mathrm{KB}$ Village area have not yet proceeded as expected.

6. Support of facilities and infrastructure in the $\mathrm{KB}$ Village in Beting Village or in Sepadu Village is available in full, but the ownership of the existing facilities and infrastructure is still unclear.

7. The achievement of program indicators for the KB Village in Beting Village on the aspect of reducing the number of KPS and KS1 cannot be identified because there is no accurate data collection yet.

8. Knowledge and community participation related to the KB Village program in Beting Village and Sepadu Village are felt to be less than optimal. In addition, information obtained from the community so far about the KB Village only comes from PPKBD/Sub PPKBD cadres, community leaders, PLKB / PKB, PKK, and from nurses/midwives.

\section{Recommendations}

Based on the results of the research, we recommend several things to improve the $\mathrm{KB}$ village program. Some recommendations are as follows:

1. For head district, it takes more attention to the $\mathrm{KB}$ village. So the activities planned by $\mathrm{KB}$ village team can be realized optimally. Then facilities that have not been fulfilled can immediately addressed.

2. For BKKBN, there is an increase in the frequency of socialization on the cross-sectors so that the information related to the $\mathrm{KB}$ Village program is clearly and evenly distributed. So that in the future there is expected to no longer the nature of the intersector is expected to be able to integrate activities in each area against activities in the $\mathrm{KB}$ village program.

3. For the OPD $\mathrm{KB}$, there is more intense advocacy of the cross-sector to understand the fact of $\mathrm{KB}$ village is not the responsibility of BKKBN or OPDKB solely, but there is joint responsibility. Thus the expected cross-sector is more active role in the development of $\mathrm{KB}$ village through the role of each sector

4. For cross-sectors, it is necessary to increase the intervention of activities in the $\mathrm{KB}$ village, because the chosen location of the $\mathrm{KB}$ village is not only due to achievement but also lag and backuping in other areas. Therefore, the responsibility of development should be taken together by the entire stake holder so that the village can compete even better can be used as a miniature district-level development area/city. In addition, monitoring and evaluation need to be done routinely so that problems happening in the field can be immediately detected and can also be resolved immediately.

5. For the KB village team, there is needed for administrative improvements ranging from recording to reporting so that the data resulting is completely accurate and the validity can be accounted for so that later expected data contained in reports can be used as a reference material for various parties to plan activities to be conducted in their managed of $\mathrm{KB}$ village.

\section{References}

Cohen, J., \& Uphoff, N. T. (1977). Rural Development Participation: Concept and Measures for Project Design-Implementation and Evaluation. New York: Cornell University Press.

Dawam, M., \& Fadila, W. (2016). Penelitian Operasional Pengembangan Model Pengelolaan kampong KB "Integrasi Program Kependudukan Keluarga Berencana 
dan Pembangunan Keluarga (KKBPK) di Village KB. Jakarta: Puslitbang Kependudukan BKKBN.

Djalal, F., \& Supriadi, D. (2001). Reformasi Pendidikan dalam Konteks Otonomi Daerah. Yogyakarta: Adicita.

Dunn, W. N. (1994). Public Policy Analysis: An Introduction. New Jersey: Prentice-Hall International, Englewood Cliffs.

Dye, T. R. (2002). Understanding Public Policy. New Jersey: Prentice-Hall, 2002

Hasanuddin, et all. (2000). Suatu Tinjauan Sejarah Sosial Ekonomi. Pontianak: Balai Kajian Sejarah dan Nilai Tradisional.

Hermawati, I., dkk. (2006). Pengkajian Keswadayaan Desa dalam Pendayagunaan Sumber Kesejahteraan Sosial. Yogyakarta: Balai Besar Penelitian Dan Pengembangan Pelayanan Kesejahteraan Sosial.

Moeljarto, T. (1987). Politik Pembangunan: Sebuah Analisis, Konsep, Arah dan Strategi. Yogyakarta: PT Tiara Wacana.

Nugroho, R. (2009). Public Policy. Jakarta: PT. Elex Media Komputindo.

Nurdin, F. (1990). Pengantar Studi Kesejahteraan Sosial. Bandung: PT Angkasa.

Prihatin, E. (2011). Teori Administarasi Pendidikan. Bandung: Alfabet.

Purwanto, E. A., dkkk. (2012). Implementasi Kebijakan Publik, Konsep dan Aplikasinya di Indonesia. Yogyakarta: Gava Media.

Rambe, A. (2004). Alokasi Pengeluaran Rumah Tangga dan Tingkat Kesejahteraan (Kasus di Kecamatan Medan, Kota Sumatera Utara) Tesis. Bogor: Sekolah Pascasarjana IPB.

Rosady, R. (2000). Kiat Dan Strategi Kampanye Publik Relation. Jakarta: PT. Raja Grafindo Persada).

SK Bupati Sambas No. 576/DP3AP2KB/2017 Tentang Pembentukkan Kelompok Kerja Daerah/Distric Working Group Kependudukan, Keluarga Berencana Dan Pembangunan Keluarga. Pemda Kabupaten Sambas.

Sudarhan, D., et. al. (2005). MenejemenPendidikan. Bandung: Alfabet.

Sudjarwo\& Basrowi. (2009). Manajemen Penelitian Sosial. Bandung: Mandar Maju.
Sumaryadi, I. N. (2010). Sosiologi Pemerintahan. Dari Perspektif Pelayanan, Pemberdayaan, Interaksi dan Sistem Kepemimpinan Pemerintahan. Jakarta: Ghalia Indonesia.

Widodo, J. (2001). Good Governance: Telaah dari Dimensi Akuntabilitas dan Kontrol Birokrasi pada Era Desentralisasi dan Otonomi Daerah. Surabaya: Insan Cendikia.

Winarno, B. (2012). Kebijakan Publik: Teori, Proses dan Studi Kasus. Yogyakarta: CAPS. 